PublisherName : BioMed Central

PublisherLocation : London

Publisherl mprintName : BioMed Central

Luiz Antônio Barreto de Castro

Dario Grattapaglia

\title{
Anti-inflammatory activity and participation of the glutamatergic system on the antinociceptive activity of ethyl acetate phase of Herisantia crispa (L.) Brizicky
}

\begin{tabular}{|c|c|}
\hline & Articlel nfo \\
\hline ArticlelD & : 3013 \\
\hline ArticleDOI & : 10.1186/1753-6561-8-S4-P268 \\
\hline ArticleCitationID & : P268 \\
\hline ArticleSequenceNumber & : 318 \\
\hline ArticleCategory & : Poster presentation \\
\hline ArticleFirstPage & $: 1$ \\
\hline ArticleLastPage & $: 3$ \\
\hline ArticleHistory & : RegistrationDate : 2014-10-1 \\
\hline & OnlineDate $\quad:$ 2014-10-1 \\
\hline ArticleCopyright & $\begin{array}{l}\text { : Souto Pereira et al.; licensee BioMed Central Ltd.2014 } \\
\text { This article is published under license to BioMed Central Ltd. This is an Open } \\
\text { Access article distributed under the terms of the Creative Commons Attribution } \\
\text { License (http://creativecommons.org/licenses/by/4.0), which permits } \\
\text { unrestricted use, distribution, and reproduction in any medium, provided the } \\
\text { original work is properly cited. The Creative Commons Public Domain } \\
\text { Dedication waiver (http://creativecommons.org/publicdomain/zero/1.0/) } \\
\text { applies to the data made available in this article, unless otherwise stated. }\end{array}$ \\
\hline ArticleGrants & : \\
\hline ArticleContext & : 1291988S4S4 \\
\hline
\end{tabular}


Charlane Kelly Souto Pereira, Aff1

Corresponding Affiliation: Aff1

Franklin Ferreira De Farias Nóbrega, Aff2

Diogo Vilar Da Fonsêca, Aff1

Míriam Graciela Da Silva Stiebbe Salvadori,Aff1

Adriana Maria Fernandes Oliveira, Aff3

Antonia Rosângela Soares Penha,Aff1

Wemerson Neves Matias, Aff1

Maria De Fátima Varderlei De Souza, Aff4

Reinaldo Nóbrega De Almeida, Aff5

Temilce Simões De Assis, Aff5

Aff1 Programa de Pós-Graduação em Produtos Naturais e Sintéticos Bioativos, UFPB, J oão Pessoa, PB, Brazil

Aff2 Unidade Acadêmica de Tecnologia do Desenvolvimento UFCG, Sumé, PB, Brazil

Aff3 Unidade Acadêmica de Ciência da Vida, UFCG, Cajazeiras, PB, Brazil

Aff4 Departamento de Ciências Farmacêuticas, UFPB, J oão Pessoa, PB, Brazil

Aff5 Departamento de Fisiologia e Patologia, UFPB, J oão Pessoa, PB, Brazil

\section{Background}

hrough the link between traditional knowledge and scientific knowledge, the importance of bieprospecting is the exploration and investigation of resources from flora and fauna in order to identify the active principles to obtain new products and processes. The integration of bioprospecting and pharmacology is an important strategy for biotechnological innovation. In this context, this study aims to contribute to the inception of a therapeutic option, particularly from natural sources, which can be effective in removing the main signs and symptoms of inflammation and pain, diminishing the problems related to drug resistance and the various toxic and side effects caused by drugs currently available. Herissantia crispa, known as malvaísco, belongs to the Malvaceae family [1] and various effects are related to this plant: antiulcer [2], antimicrobial [2] and antinociceptive [3]. The aim of this study was to evaluate the anti-inflammatory activity and participation of the glutamatergic system in the antinociceptive effect of the ethyl acetate phase of Herissantia crispa (FAEHc). 


\section{Methods}

Swiss male mice, 25 - $35 \mathrm{~g}$, divided into experimental (250, 500 or $750 \mathrm{mg} / \mathrm{kg}$ ), control (vehicle) and standard (dexamethasone or MK-801) groups. All procedures were approved by the Ethics Committee (CEUA) at UFPB, \# 0106/10. Carrageenan (1\%) was administered into the right hind paw in the carrageenan-induced paw edema assay. Paw thickness was measured 1, 2, 3, 4, 6 and 24 hours later. In the test of glutamate-induced nociception all animals were observed individually for $15 \mathrm{~min}$, following glutamate injection $(20 \mu \mathrm{L})$ into the right hind paw. Values were analyzed by one-way ANOVA followed by Dunnett's post-test's, expressed as mean \pm sem and percentage $(n=8)$. Results with $P<0.05$ were considered statistically significant.

\section{Results}

In the carrageenan-induced edema assay, $\operatorname{FAEHc}(250,500$ and $750 \mathrm{mg} / \mathrm{kg})$ after one hour, reduced the paw edema $40 \%, 50 \%$ and $50 \%$ respectively compared to the control group $(1.0 \pm 0.1 \mathrm{~cm})$. After two hours, FAEHc reduced $250(40 \%), 500(60 \%)$ and $750 \mathrm{mg} / \mathrm{kg}(40 \%)$ compared to control $(1.0 \pm 0.1 \mathrm{~cm})$. At the third hour, FAEHc reduced 250 (45.5\%), 500 and 750: (54.5\%) compared to control $(1.1 \pm 0.1 \mathrm{~cm})$. at the fourth hour FAEHc showed similar reduction of edema at all doses $(46.2 \%)$ compared to control (1.3 $\pm 0.1 \mathrm{~cm})$. At the sixth hour, 250: (36.4\%), 500: (45.4\%) and 750: (36.4\%) compared to control (1.1 \pm $0.1 \mathrm{~cm}) .24$ hours after treatment FAEHc reduced $250(57.1 \%), 500(71.4 \%)$ and $750(57.1 \%)$ respectively, compared to control $(1.4 \pm 0.1 \mathrm{~cm}) .24$ hours after administration of carrageenan, dexamethasone reduced edema at 1 hour: $40.0 \%, 2$ hours: $60.0 \%, 3$ hours: $54.4 \%, 4$ hours: $69.2 \%, 6$ hours: $63.6 \%$ and 24 hours: $50.0 \%$. The results showed suggest that FAEHc has antiedematogenic effect. FAEHc $(750 \mathrm{mg} / \mathrm{kg})$ showed significant reduction in paw licking time by $84.0 \%$ compared to control $(56.9 \pm 3.9 \mathrm{~s})$; since FAEHc decreased the effect produced by glutamate, it is possible that its antinociceptive effect is related to glutamatergic system. The results of this study indicate that FAEHc has glutamatergic- related antinociception and anti-inflammatory properties.

\section{Acknowledgements}

UFPB, UFCG, CAPES.

\section{References}

1. Agra MF, Silva KN, Basílio IJ LD, Freitas PF, Barbosa-Filho J M: Survey of medicinal plants used in the region northeast of Brazil. Rev Bras Farmacogn. 2008, 18 (3): 472-508. 10.1590/S0102$695 \times 2008000300023$.

2. Lima IO, Costa VBM, Matias WN, Costa DA, Silva DA, Agra MF, Souza MFV, Lima EO, Batista LM: Biological activity of Herissantia crispa (L.) Brizicky. Rev Bras Farmacogn. 2009, 19: 249-254. 10.1590/S0102-695X2009000200012.

3. Pereira CKS, Oliveira AMF, Penha ARS, Teles YCF, Matias WN, Souza MFV, Almeida RN, Assis TS: Antinociceptive effect of the ethanol crude extract of Herissantia crispa (L.) Brizicky. J Med Plants Res. 2012, 6 (47): 5813-5818. 